\title{
Factors necessary for effective corporate waqf management for Malaysian public healthcare
}

\author{
Raja Aishah binti Raja Adnan and Mahazan Abdul Mutalib \\ Faculty of Leadership and Management, Universiti Sains Islam Malaysia (USIM), \\ Nilai, Malaysia, and \\ Muhammad Ridhwan Ab. Aziz \\ Faculty of Economics and Muamalat, Universiti Sains Islam Malaysia (USIM), \\ Nilai, Malaysia
}

\begin{abstract}
Purpose - This research paper aims to determine the factors needed to propose a platform where waqf (Islamic endowment) organizations can collaborate with government public hospitals to develop corporate waqf hospitals. Consequently, the elements of governance and sustainability are included in the management of corporate waqf hospitals thereby leading to the corporatization of public hospitals.

Design/methodology/approach - This study adopts the qualitative research methodology and undertakes content analysis of data collected from journal articles, magazines and official websites. Data analysis involves open coding with NVivo 12.

Findings - General findings from the literature review have shown that architectural and engineering fundamentals were essential factors in the success of past waqf hospitals of the era between 8th and 14th centuries. In that era, the decentralized waqf-based hospitals employed the mutawall (the trustee/manager of the waqf assets) to govern the administration of the hospitals. Present corporate waqf hospitals can exploit the elements identified from past waqfbased hospitals and additionally adopt the private-public partnership model in the form of a mudarabah (profitsharing contract) agreement to design a sustainable waqf governance model for Malaysian public healthcare services. Research limitations/implications - The proposed platform is designed for a corporate waqf model developed in collaboration between Malaysian waqf institutions and public healthcare services. It abides by both the Malaysian fatwa (Islamic rulings) on waqf and the laws of the Malaysian Government.

Practical implications - There is potential for developing the Malaysian corporate waqf-governance healthcare model which will enable the hospital to provide better quality healthcare to more patients through upgrading the quality of equipment used in hospitals and/or better facilities at equal or lower costs. Consequently, this will not only improve waqf management and distribution but also result in reduction of government expenditure.

Social implications - This research promotes the concept of a corporate waqf hospital which will provide innumerable beneficial healthcare services in terms of improved healthcare quality at affordable costs to the general public and at no cost to the poor and the underprivileged.

Originality/value - Although waqf has played an important role as a vehicle for Islamic financing in the society for centuries, a model of collaboration or partnership of waqf with public healthcare services has yet to be explored and developed. With proper corporate governance and well-managed sustainability in a corporate waqf model, this newly developed partnership between waqf institutions and public healthcare providers can be a first step in many more interesting collaborative arrangements that can be established between waqf institutions and public services in the future.
\end{abstract}

Keywords Decentralization, Healthcare, Islamic social finance, Mudārabah, Public-private partnership, Waqf governance

Paper type Research paper

(C) Raja Aishah binti Raja Adnan, Mahazan Abdul Mutalib and Muhammad Ridhwan Ab. Aziz. Published in ISRA International Journal of Islamic Finance. Published by Emerald Publishing Limited. This article is published under the Creative Commons Attribution (CC BY 4.0) licence. Anyone may reproduce, distribute, translate and create derivative works of this article (for both commercial and noncommercial purposes), subject to full attribution to the original publication and authors. The full terms of this licence may be seen at http://creativecommons.org/licences/by/4.0/legalcode
Effective corporate waqf management

Received 4 January 2020

Revised 6 February 2020 16 May 2020 20 June 2020

10 September 2020

12 July 2021

16 July 2021

5 August 2021

9 September 2021

17 September 2021

4 October 2021

Accepted 27 October 2021

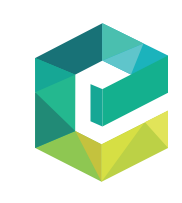

ISRA International Journal of Islamic Finance Vol. 14 No. 1,2022
pp. $73-88$ Emerald Publishing Limite e-ISSN: 2289-4365 p-ISSN: 0128-1976 DOI 10.1108/IJIF-11-2019-0178 
IJIF

14,1

\section{Introduction}

The workload in public healthcare organizations has dramatically increased due to increasing health needs throughout the years and the demand for better healthcare facilities. Malaysian policymakers have suggested several models such as privatization, corporatization and social healthcare insurance as remedies to alleviate the crisis in healthcare services (Croke et al., 2019). Privatization was hailed as a panacea to all those problems and was sought to improve efficiency and reduce costs (Chee-Khoon, 2007; World Health Assembly 53, 2000). However, privatization comes with increased medical costs. With rising costs of healthcare, the healthcare system needs restructuring by the government. Malaysian public healthcare needs more subsidies as demand exceeds the services available. Additionally, the fee disparity between public and private healthcare services adds to this dilemma. The World Health Organization (WHO) recommends a merger of some successful healthcare models that involve monetary parties and are governed by privatization/ corporatization services (World Health Assembly 53, 2000; Brinkerhoff et al., 2019). Another alternative is the welfare approach applied in social-based healthcare services in providing and optimizing the society's healthcare needs.

Waqf (Islamic endowment) is known to have played an important role historically in providing healthcare and other public services in Islamic societies. In fact, it was the waqf system that exclusively provided public services in the education, healthcare and military sectors. However, waqf has not been utilized fully and effectively to improve health services in the present context, particularly in Malaysia. Waqf institutions could contribute and collaborate with government public healthcare agencies such as hospitals to offer numerous benefits to the multi-religious, multi-racial citizens of Malaysia in this era of high medical costs. However, certain conditions must be laid down for a successful collaboration.

Hence, this research investigates the elements necessary to build a platform that allows waqf organizations to work in partnership with public healthcare providers and that facilitates good governance. This model is crucial as it not only demands legitimacy and feasibility of the proposed platform between waqf institutions and government public hospitals but also incorporates the elements of good governance and sustainability. The model will then be an enabler of organizational transformation which can promote corporate waqf hospitals with numerous beneficial healthcare services and improved healthcare quality at affordable costs. The research objectives are therefore to:

(1) determine and recognize the elements of waqf-based hospitals from past and current models in the literature;

(2) identify other elements which are important to the proposed corporate waqf hospital; and

(3) draw up a conceptual framework of a platform that will facilitate collaboration of waqf institutions with public government hospitals, resulting in a working corporate waqf hospital model.

This collaborative platform will be an enabler for waqf institutions and public government hospitals to promote understanding of the Islamic perspective of fund management from waqf sources and simplify interaction in the corporate working atmosphere. The platform will also be an innovative solution for waqf institutions and public services.

\section{Literature review}

In determining the design of the platform mentioned earlier, some factors have already been identified from the overall readings of journal articles relating to concepts such as waqf, decentralization and public-private partnerships (PPPs). The following reviews the literature on these factors that are essential for establishing the proposed platform of waqf institutions 
and public government hospitals to develop a corporate waqf hospital model. This type of collaboration can be a new initiative and an addition to the existing models of hospitals in the health services sector.

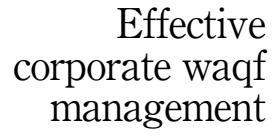

\section{Waqf-based hospitals in history (8th-14th centuries CE)}

Waqf plays an important role as a socio-economic contributor as it is an important Islamic institution that transforms alms, donations and contributions into public services in perpetuity (Çizakça, 1998). History has indeed proven that public social services, when financed by private endowments, will result in reducing the country's budget deficit. This can be the solution to the undersupply of public goods in the modern world of conventional economies. According to Saduman and Aysun (2009), during the Ottoman era, the cash waqf fund not only supplemented the zakat (alms) fund and provided financial support to the poor and needy, it also contributed to the development of public infrastructure. As such, modern economists should consider the waqf system to complement the present economic system.

The history of waqf has been recorded in innumerable journal articles and books. Waqf in the health services sector began as early as the era of the Prophet (peace be upon him) in the form of a mobile military tent where Rufaydah was the first female nurse to take care of wounded patients during Ghazwat Khandaq (the Battle of the Trench) (Al-Bukhari, 1375). The first Muslim hospital, an asylum for lepers, was constructed in the early eighth century CE in Damascus under the Umayyad Caliph Walid ibn 'Abd al-Malik (Abouleish, 1979; Sayili, 2006; Tschanz, 2017). From the 8th to the 14th century CE, waqf-based hospitals were successful in their endeavor to serve the public. Key elements of that phenomenon have been identified by past studies (Adnan et al., 2020); amongst them were architectural and engineering elements, decentralization, the role of the mutawalt as a governance tool and the importance of sustainability.

The golden Islamic era of the 8-14th centuries CE brought about the development of Islamic medical hospitals which became the pinnacle of Islamic civilization, where the humanitarian features of waqf were integrated with the best available medical knowledge (Sayili, 2006). This resulted in a dynamic and organized institution. Waqf-based hospitals of that era adopted a decentralized management model; the role of the central authority was minimal (Hamouche, 2007), community participation was emphasized and the historical provisions of making available free healthcare were protected (Nour, 2015).

It is noted that there is a lack of studies that have examined the business framework and administrative management of past waqf-based hospitals and the impact of these institutions on the social, political and economic dimensions of their societies. The studies found focused mainly on their architectural features (Al-Ahmad, 2014; Dāhir, 2015) and role in urban regeneration (Nour, 2012, 2015).

\section{Decentralization}

Decentralization (the reallocation of authority) repositions responsibility and public funds for the provision of public goods amid varying ranks of government. Decentralization is the assignment of jobs relating to planning, financing and management from the central government to the lower units of government such as in districts, sub-districts, villages, municipalities and city corporations (Rondinelli et al., 1989; World Bank, 2019). Important benefits of decentralization include good governance (Goel et al., 2017), the empowerment of local communities (Tkachenko and Kulyk, 2019) and community building capacities. When this is supported by partnership with the centralized systems it can further enhance the success of decentralization within the localities (Taamneh et al., 2019). In a nutshell, the result of decentralization is that when organizations are structured in smaller organizations and are managed correctly, they are naturally more responsive and accountable than larger organizations (Fadime et al., 2013). 
IJIF

14,1

The important elements in decentralization are the principles of transparency and accountability which work best at the local level whereby trust is nurtured and consequently the quality of public services is improved (Isufaj, 2014). Decentralization may also generate increased accountability and bottom-up monitoring (Maino et al., 2007) whereby the civil society acts actively in providing focused information to improve service delivery (Maino et al., 2007; Raffler et al., 2019). Decentralization not only improves governance in developing countries; it also enhances public service delivery through the allocation of funds in much needed services whilst developing accountability throughout local governments, with less bureaucracy and offering increased opportunities for the local people (World Health Assembly 53, 2000; Andersson and Ostrom, 2008; Regmi et al., 2010; UNDP/EU, 2019). It also leads to less corruption within bureaucratic nations (Freille et al., 2007; Chalil, 2020).

The literature review on governance and accountability in non-profit and charitable organizations has paved the way for consideration of waqf governance. In the case of nonprofit organizations, there are no shareholders, only board trustees. The board is entrusted to ensure that the organization carries out its mission, not to benefit any specific individual but to benefit its clients. All non-profit organizations and associations have a binding legal commitment to this principle (Drucker, 2011; Anheier, 2014).

Currently, the waqf reporting practice is based on the conventional accounting system. This has the weakness of limiting the reporting coverage to annual financial information only (Masruki and Shafii, 2013; Mansor et al., 2018). Governance in waqf is important as it promotes transparency and accountability, and these are crucial for a sector that relies on the confidence and trust of its stakeholders (Shafii et al., 2015). Second, it practically reflects the sacred accountability towards Allah (SWT) (Nahar and Yaacob, 2011). Waqf-based organizations, as in the case of other social-based organizations in the non-profit sector, self-monitor themselves and are even unsupervised in some cases. It is acknowledged that for-profit organizations comply better in providing financial reports in accordance with international financial reporting standards. Conversely, nonprofit organizations are less regulated and lacking in the development of financial reporting requirements and therefore need new measures to increase accounting disclosure to bring about added social and economic value in their activities (Cordery and Baskerville, 2007; Albaz, 2019). In Malaysia, financial reporting and the governance framework for non-government organizations has yet to be established to ensure effective monitoring (Farouk and Wing, 2019).

Therefore, the dual accountability involved in waqf management (via the conventional accounting system and the sacred accountability vis-à-vis Allah (SWT)) and decentralization of corporate governance can benefit waqf organizations in better managing transparency and accountability and ensuring trustworthiness in waqf management (Nahar and Yaacob, 2011; Saad et al., 2017).

\section{Decentralization in healthcare}

Decentralization in healthcare has evolved and progressed in different countries with different working cultures. The focus of decentralization in healthcare is on alleviating poverty by making the government closer to fulfilling the needs of people (Asante and Ayee, 2008; Galasso and Ravallion, 2005; Vrangbæk, 2007; White, 2011).

Healthcare is a heterogeneous service product; demands for medicines and treatment are likely to vary as different types of diseases may vary in prevalence in different locations, and healthcare services need to adapt to the varying local needs. Hence, decentralization will allow for crucial adaptations in the myriad range of healthcare services. This can only be achieved by getting local governments involved in the key service delivery points. Healthcare service delivery will also become more efficient when it is prescribed upon demand.

Decentralization of health policies and funding has been proven to improve efficiency in healthcare (Kälin, 1999; Phommasack et al., 2005; Vrangbæk, 2007; Guanais and Macinko, 2009; 
Regmi et al., 2010; Alves et al., 2013; Isufaj, 2014; Goel et al., 2017; Costa-Font and Perdikis, 2018). The trend toward adopting decentralization has been promoted by major international organizations such as the International Monetary Fund, the United Nations and the World Bank (Goel et al., 2017). Conversely, the disadvantages of decentralization have raised some concerns relating to the quality of healthcare, implementation of poor policies, poor managerial capabilities, and poor regulation over the control of finance and human resources (Prud'homme, 1995; Shah and Thompson, 2004; Oates, 2006; Regmi et al., 2010; Goel et al., 2017).

Nonetheless, looking beyond a single structure of decentralization, polycentric structures give a wider perspective. Table 1 compares the important elements in each of the structures mentioned therein and defines the characteristics of each model applied in waqf management and administration in the past and current modern legalized systems over time.

The complexity of the different structures may produce a more sophisticated governance system and can accommodate the main focus of this research, which is waqf. Aptly, in the structure of decentralization, there is no ideal single model for all organizations. Hence, each state has to determine and develop its own model from the culture of the people and the constitutional and legal arrangements what best suits its own country and economic conditions (Kälin, 1999; Koivusalo et al., 2007; Tobbala, 2019). The purpose of the decentralization is only the focal point of the formation of the framework. The polycentricism explained confirms the ability of waqf to be versatile in its management of different waqf contributions in various public organizations.

In the management of waqf, two management styles were mentioned in the literature, namely:

(1) decentralization (Hamouche, 2007; Babacan, 2011; Shefer-Mossensohn, 2014; Yaacob et al., 2015; Elasrag, 2017) and

(2) polycentricism (Kuran, 2001; Babacan, 2011; Suhaili et al., 2018).

In waqf management of past waqf-based hospitals, the decentralized management style was adopted where each waqf was managed independently according to its specific rules and conditions as defined by the founder (Hamouche, 2007; Nour, 2012; Çizakça, 2013). This approach helps to protect the waqf buildings and allows transparency, with fewer mistakes and failures (Nour, 2012; Shefer-Mossensohn, 2014; O'Grady, 2019).

\begin{tabular}{|c|c|c|c|}
\hline $\begin{array}{l}\text { Defining } \\
\text { characteristics }\end{array}$ & $\begin{array}{l}\text { Mainstream decentralization } \\
\text { literature }\end{array}$ & Centralised approach & $\begin{array}{l}\text { Polycentric analytical } \\
\text { approach }\end{array}$ \\
\hline Unit of analysis & Local government & $\begin{array}{l}\text { Urban services, } \\
\text { traditional bureaucracy }\end{array}$ & $\begin{array}{l}\text { Territorial focus, local } \\
\text { governance }\end{array}$ \\
\hline $\begin{array}{l}\text { Policy aspect } \\
\text { emphasized }\end{array}$ & $\begin{array}{l}\text { Scope, fit or environmental } \\
\text { outcomes }\end{array}$ & Scope, limited size & $\begin{array}{l}\text { Scope, fit and } \\
\text { environmental outcomes }\end{array}$ \\
\hline Key variables & $\begin{array}{l}\text { Accountability, financial and } \\
\text { human capacity }\end{array}$ & $\begin{array}{l}\text { Accountability, political } \\
\text { and authority }\end{array}$ & $\begin{array}{l}\text { Underlying incentive } \\
\text { structures }\end{array}$ \\
\hline
\end{tabular}

The application of structures in waqf systems in different eras

Era Pre-modern system

Administration/

Supervision

Autonomous

management: single trustee (mutawwalli) single waqf
All waqf administered by a single ministry department
Modern system

Corporate governance: different organizations administer a number of assets of waqf, but not all the assets
Table 1.

Comparison of features of decentralization, centralization and polycentric approaches in supporting their
applications in waqf in different eras

\section{Effective corporate waqf management} Gruby (2019) 
IJIF

14,1

\section{8}

The definitions of polycentricism (Ostrom, 1972; McGinnis, 2005; Carlisle and Gruby, 2019) show that the important elements are similar to those of the decentralization structure but on a bigger scale with multiple numbers of components involved. Among them are multiple elements adapting independently within a localized area, and multiple centers for decision-making to be performed exclusively. Polycentricism in waqf proved to be advantageous in the provision of social services, including public goods, as it allowed the fine tuning of services and encourages experimentation (Kuran, 2001; Thiel, 2016; Mathias et al., 2017; Ibrahim et al., 2019). With its element of adaptation, it offers waqf founders with varied choices and diverse opportunities (Kuran, 2001). The polycentricity concept offers prospects not only for discoveries, experimentations and involvement (Schoon et al., 2015) but also improves communication and overall governance (Thiel, 2016), provides healthy accountability, and promotes teamwork (Merwe et al., 2018).

\section{Public-private partnerships}

PPPs relate to projects that hinge on a contract between a public agency and a private entity (for-profit or not-for-profit) in the provision of services, facilities and/or equipment (Independent Evaluation Group, 2016). The aim of PPPs is to utilize collaborations in the joint use of resources and in the application of management knowledge, resulting in good outcomes for all parties (Sundaram and Chowdhury, 2009).

Table 2 shows the summary of literature reviewed by the authors on the progression of PPPs of healthcare services and the necessary elements that are needed to improve such partnerships. They have identified the following important requirements for a successful partnership: sustainability, incentives, support and governance.

When comparing the categories of PPP, namely public health services PPP, hospital services PPP, finance PPP and other types of PPP (Independent Evaluation Group, 2016), it is found that there is a research gap on the aspect of collaboration between waqf organizations and public service organizations.

\section{Public-private partnerships in Malaysia}

According to Nexus Partnerships Limited (2019), the Malaysian Government introduced the "Malaysia Incorporated Policy" in 1983, which promoted collaboration between private and

\begin{tabular}{|c|c|c|}
\hline & Citations & Concluding key factors \\
\hline 1 & $\begin{array}{l}\text { Birla and Taneja } \\
(2008)\end{array}$ & $\begin{array}{l}\text { PPPs can become one of the most useful models for quality healthcare services to } \\
\text { reach the vast majority of people }\end{array}$ \\
\hline 2 & Raman (2012) & $\begin{array}{l}\text { PPPs represent partnership with private entities and not privatization. The } \\
\text { concept involves a new role for government and requires reform of the public } \\
\text { sector for efficiency of PPPs }\end{array}$ \\
\hline 3 & $\begin{array}{l}\text { Ismail and Harris } \\
(2014)\end{array}$ & $\begin{array}{l}\text { There is a need to establish proper guidelines on PPPs to continue developing PPP } \\
\text { implementation in Malaysia }\end{array}$ \\
\hline 4 & Jensen (2016) & $\begin{array}{l}\text { It investigates the important elements of the partnership and questions the } \\
\text { sustainability and incentives aspects that are crucial for the final impact of PPP in } \\
\text { healthcare }\end{array}$ \\
\hline 5 & $\begin{array}{l}\text { Abuzaineh et al. } \\
\text { (2018) }\end{array}$ & $\begin{array}{l}\text { PPPs must be designed within the local context and be aligned with a country's } \\
\text { national or local healthcare policies and delivery strategy }\end{array}$ \\
\hline 6 & Hamzi et al. (2020) & $\begin{array}{l}\text { An overview of PPP stories and their successes conducted in Malaysia concludes } \\
\text { that PPP is one of the ways forward in the healthcare industry }\end{array}$ \\
\hline \multicolumn{3}{|c|}{ Source(s): Authors' own } \\
\hline
\end{tabular}

Table 2.

Journal articles about PPPs in healthcare services 
public organizations to result in the development of a single entity in the form of a "Malaysian Company". The PPP initiative involved the public sector formulating most of the policies, determining the direction and providing specialized supporting services aimed at reducing the country's budget deficit, developing manufacturing production, fostering economic growth, cutting down on the scope of government spending and accomplishing the country's economic policies (Sapri et al., 2016; Rafie and Shuib, 2018). Some successful PPP projects are the North-South Highway, Light Rail Transit (LRT), Tanjung Pelepas Port, Kuala Lumpur International Airport (KLIA), Tenaga Nasional Berhad (National Electricity Board) and Telekom Malaysia Berhad (UKAS, 2021).

\section{Partnership and waqf}

According to Abdallah (2010), waqf in early Islam began with the concept of partnership. He observes that a PPP of the state and waqf organizations would uphold the context of waqf, increase effectiveness and build sustainable cooperation. Islamic partnerships were known to commence as early as the 7th CE and was known in classical Islam as mudārabah (sleeping partnership) (Çizakça, 1996; Amer et al., 2014). It began in the early medieval period as a commenda, which was an arrangement whereby the principal entrusts his capital or merchandise to an agent or manager who trades with it and returns with the principal and agreed-upon profits. The agent then is rewarded for his entrepreneurship. Only the investor bears the loss (Kuran, 2003; Hassan, 2007; Udovitch, 2011; Baldwin and Sukmana, 2016). In waqf, cash can be invested in a mudārabah and the profit used to provide charity to the needy (beneficiaries) (Abdul Aziz et al., 2019).

The partnership of public-private funding in public-operated hospitals can be a new experience and may prove to be challenging with many positive possibilities. The said partnership offers a potential collaboration for waqf organizations and public healthcare services. In overcoming costly healthcare worldwide, governments are considering PPPs with private sector entities. The key objectives of a PPP model for healthcare improvements are the following:

(1) to improve and develop operations of public health services and facilities;

(2) to use private investments for the provision of public goods;

(3) to help build infrastructure with non-profit partners in public services; and

(4) to expand the scope for partnering with governments in the private healthcare sector (Independent Evaluation Group, 2016).

Mudārabah, according to the Shariah Standard on Mudārabah published by Bank Negara Malaysia (2012), is a contract between a rabb al-māi (capital provider) and a mudari $\bar{b}$ (entrepreneur) for the latter to manage the capital and for sharing of profits generated from the capital between the $r a b b$ al-ma $l$ and the mudarib according to the mutually agreed profitsharing ratio (PSR). With regard to financial losses, they are borne by the rabb al-māl provided that such losses are not due to the mudari $\bar{b}$ 's ta'addi (misconduct), taqșir (negligence) or mukhälafat al-shurūt (breach of specified terms).

The two-tier mudārabah in a cash waqf model, as mentioned by Mobin and Ahmad (2017), involves the classical mudārabah agreement in the first tier, including the waqf provider or giver and the owner of the capital $(r a b b a l-m \bar{a})$. The waqf provider or giver comprises individuals and/or organizations and the $r a b b a l-m \bar{a} l$ is the capital provider or trustee/fund manager. The second tier of the mudārabah agreement involves the rabb al-māl and the transference of the capital to the mudari $b$ to employ the funds in some profitable venture. The $m u d a \bar{r} b$ is an entrepreneur. To simplify the waqf and its partnership, a muda $\operatorname{arabah}$ model is visualized in Figure 1. 
IJIF

80

Figure 1.

Two-tier mudārabah
Findings from past literature on factors essential for constructing a collaborative platform between waqf institutions and public hospitals

From a literature review of the success of past waqf-based hospitals in different eras, it is noted that waqf has successfully evolved over time and has been integrated in its respective cultures and civilizations. Therefore, it is evident that this approach can be emulated, developed further and adopted in the present and the future. Research has helped to narrow down some factors that are essential for the construction of a platform for collaboration between waqf institutions and public hospitals. Findings include the following:

(1) Coding from NVivo 12 has identified the essential factors for the success of past waqf hospitals during the 8th-14th centuries CE period to achieve research objective 1 of this study. These essential factors in past waqf-based hospitals are depicted in Figure 2.

From Figure 2, the essential factors found in past waqf-based hospitals are architectural elements and good infrastructure, decentralization and sustainability. The architectural elements were in the form of beautifully designed buildings of culture and splendor which were erected with purpose-built facilities like fever wards with cooling water fountains (Al-Maqrīzi, n.d.; 'Isāā, 1981; Nowsheravi, 1983; Sayili, 2006).

Another element for the platform is decentralized management. Coding for this element using NVivo 12 found that literature discussed the implementation of decentralized management in a positive note in both the present and the past. It is associated with efficiency, good governance, better communication and cooperation, delegation of power, responsibilities and authority, and better understanding. The golden Islamic era of the 8th ${ }^{-14}$ th centuries CE brought about the development of Islamic medical hospitals that became the pinnacle of Islamic civilization, where the humanitarian features of waqf were integrated with the best available medical knowledge (Sayili, 2006).

The rise of corporate waqf in recent years provides a new dimension of waqf practices. The present era has produced an element of corporate waqf governance within which a sound

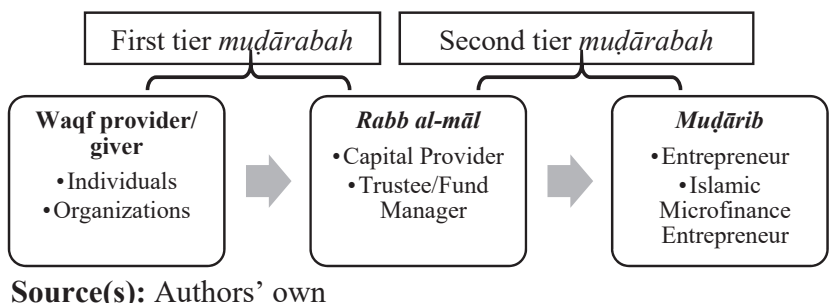

Source(s): Authors' own
Figure 2.

Essential factors in past waqf-based hospitals

Past waqf-based hospitals during 8th-14th CE

Architectural elements and good infrastructure

(Al-Ahmad, 2014; Dāhir, 2015)

Source(s): Hamouche (2007), Nour (2012, 2015), Al-Ahmad (2014), Dāhir (2015) institutions/foundations

(Nour, 2012; 2015)
Sustainability

(Hamouche, 2007)

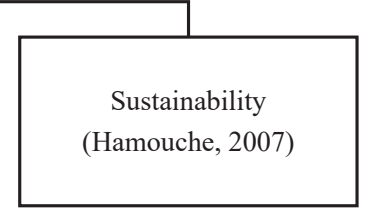


governance system can be established that would attract government-linked companies/ government-linked investment companies, private corporations and individuals to collaborate in waqf activities (Ramli et al., 2015). The moral principles behind corporate governance comprise ethical behavior, accountability, transparency and sustainability, which promote an organization's long-term value (Hanefah et al., 2020). Hence, embedding an Islamic corporate governance culture in waqf management can only enhance the functions of waqf institutions and prove beneficial for them (Hassan and Noor, 2020).

(2) An element found necessary for the setting up of the platform that answers research objective 2 of this study is the mudārabah agreement.

The visualization from NVivo 12 shows the common coding of 13 articles which mention partnerships and suggest mudārabah agreement with waqf organizations. A few of the codings from the 13 articles also discuss the efficient management of waqf funds (Ahmad, 2015), benefits from partnership (Mobin and Ahmad, 2017), increasing waqf income and strengthening waqf's competence in alleviating poverty (Al-Ahmad, 2014) and ensuring fairness within Shari'ah parameters (Mobin and Ahmad, 2017).

In a cash waqf model, as depicted in Figure 3, the two-tier muda arabah was chosen for the proposed platform. The healthcare services of a public government hospital are adapted into the diagram to show the possibilities of developing collaboration between waqf institutions and the healthcare sector.

Key elements for designing the platform for a sustainable waqf-governance model

Based on the above findings, the following are the key elements for designing a suitable platform to create a sustainable waqf-governance model for Malaysian public healthcare services:

(1) Architectural design and decentralized management, which are important elements found in the literature on historical waqf-based hospitals;

(2) Corporate governance, which is an important factor in the management of present waqf hospitals;

(3) PPP through a mudāarabah agreement, which is an element proposed in this research; and

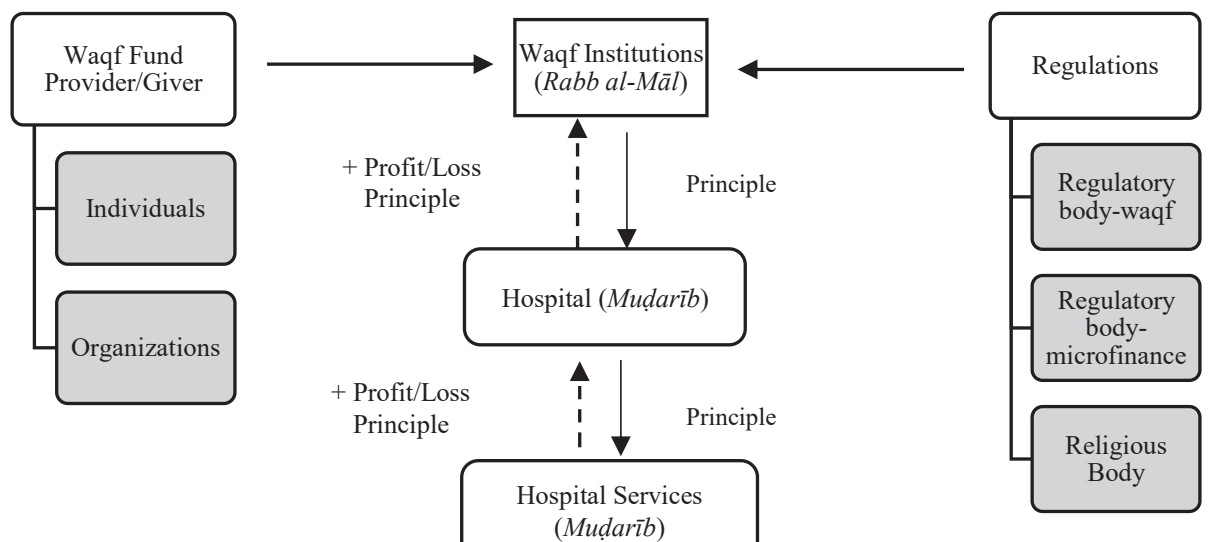

Figure 3.

Two-tier mudāarabah waqf PPP model

Source(s): Adapted from Hassan (2016)

\section{corporate waqf management}


IJIF

\section{4,1}

82

(4) Shariah compliance and conformity to the requisites of waqf, which represent the foundation of this platform.

These main features will complement each other and help in developing a sturdy platform for the "partnership" of waqf funds and public services - which in this case is between waqf organizations and government public hospitals - to work together and progress in the development of a successful and working model of a corporate waqf-based hospital institution.

\section{Platform for a sustainable waqf governance model for Malaysian public healthcare}

In designing a platform for a sustainable waqf governance model for Malaysian public healthcare services, the essential factors have been identified in this research. In light of the above findings, a framework is drawn in Figure 4 below which fulfils research objective 3 of this study.

The design of the platform is specifically for a waqf institution that partners with a government public hospital and is structured upon the essential factors of waqf elements, decentralized management, corporate governance and mudārabah agreement as the underlying bases of the framework.

The waqf funds are raised from key funders such as government, waqf institutions and the public. This will be managed by the board of directors which acts as the mutawalt and which will consist of members from the public government hospital and the waqf institution. The operations will be managed predominantly by the public government hospital. With proper corporate governance and consideration of economic sustainability, this partnership between waqf institutions and public healthcare services can lead to much more interesting collaboration between waqf and other public services in the future.

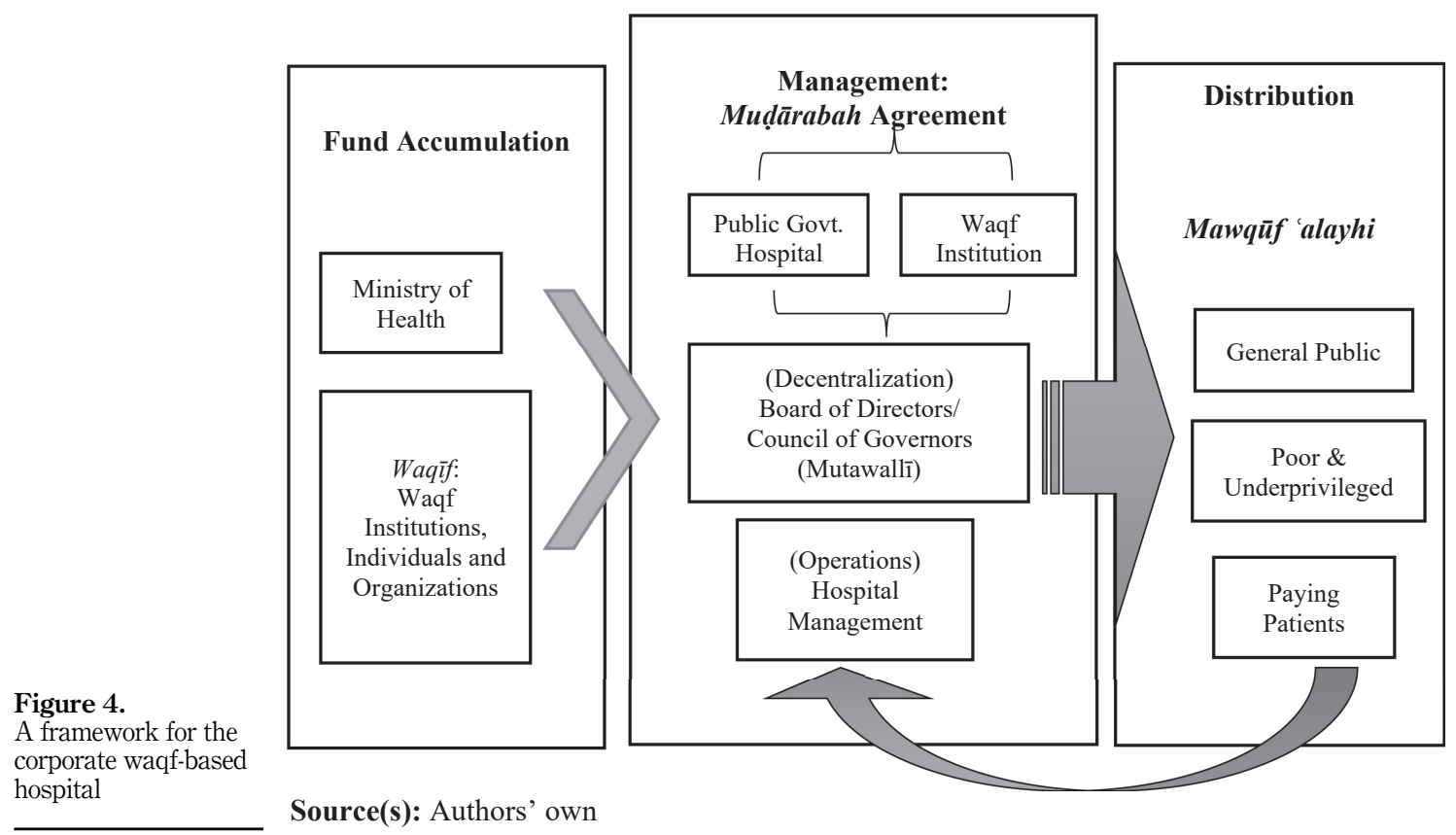

Figure 4.

A framework for the hospital 
In Figure 4, the healthcare services of a public government hospital are adapted into the diagram to show the possibilities of developing collaboration between waqf institutions and the healthcare sector.

\section{Conclusion}

The platform developed in this research is a new proposition for waqf development in achieving economic sustainability. With its identified essential factors, it can also be used for developing other myriad collaborations between waqf institutions and other public services such as water, communications and education.

Further studies are encouraged to investigate legal issues relating to the working partnership of the PPP and to provide clarity as to how this partnership can be established to create a corporate PPP. There are only a few guidelines on PPP implementation in Malaysia; and thus the need for establishing clear guidelines and procedures on PPP is considered important by key players in this industry. Furthermore, the governance and operationalization of the working model were not discussed in depth in this research and therefore studies and surveys can be conducted to query waqf funders and other stakeholders on the practicality of the model. Finally, further research can also involve the use of Islamic working ethics in the operations of the corporate waqf hospital which can present new dimensions and core values that would enrich the culture of the proposed hospital.

\section{References}

Abdallah, T. (2010), "The state and $a w q \bar{a} f$ (charitable endowments) in the twenty-first century: from tutelage to partnership", Contemporary Arab Affairs, Vol. 3 No. 4, pp. 503-514.

Abdul Aziz, A.H.B., Zhang, W., Hamid, B.A., Mahomed, Z., Bouheraoua, S., Kasri, N.S. and Sano, M.A.A. (2019), Maximizing Social Impact through Waqf Solutions, The World Bank, Washington DC.

Abouleish, E. (1979), Contributions of Islam to Medicine, Islamic Medical Association of North America, Vol. 10, pp. 28-45, (June).

Abuzaineh, N., Brashers, E., Foong, S., Feachem, R. and Da Rita, P. (2018), "PPPs in healthcare: models, lessons and trends for the future", Healthcare Public-Private Partnership Series, No. 4, Institute for Global Health Sciences, University of California, San Francisco and PwC, New York, available at: https:/globalhealthsciences.ucsf.edu/sites/globalhealthsciences.ucsf.edu/ files/pub/ppp-report-series-business-model.pdf (accessed 30 December 2020).

Adnan, R., Mutalib, M. and Aziz, M. (2020), "Insights into the historical management of past waqfbased hospitals", Islamic Quaterly, Vol. 64 No. 2, pp. 213-240.

Ahmad, M. (2015), "Role of waqf in sustainable economic development and poverty alleviation: Bangladesh perspective", Journal of Law, Vol. 42, pp. 2224-3259.

Al-Ahmad, A. (2014), Waqf, the Charity and the Common, Exploring the Waqf beyond the Religious, the Institutional, the Customary: The Gaza Camp Experiment, available at: https://issuu.com/ assilaal-ahmad/docs/exploring_the_waqf_-_chapter_1 (accessed 26 January 2019).

Al-Bukhari (1375), "Kitab Ar Rasail”, in Al Adab Al Mufrad, Dar Al Siddiq, Saudi Arabia, p. 351.

Al-Maqrīzi, A.B.A. (n.d), Al-Mawaiz Wa al-tibiār bizikir al-Khuțț Wa al-Āthār, Dār al-Kutub al-Ilmiyah, Beirūt.

Albaz, M. (2019), "Core perspectives of performance measurement in NPOs: in search of accountability and legitimacy", Economic Archive, Vol. 3, pp. 3-16.

Alves, J., Peralta, S. and Perelman, J. (2013), "Efficiency and equity consequences of decentralization in health : an economic perspective", Revista Portuguesa de Saúde Pública, Vol. 31 No. 1, pp. 74-83, doi: 10.1016/j.rpsp.2013.01.002. 
IJIF

14,1

Amer, S., Anees, M. and Sajjad, M. (2014), "Mudarabah: a new paradigm for corporate governance", European Journal of Business and Management, Vol. 6 No. 6, pp. 98-102.

Andersson, K.P. and Ostrom, E. (2008), "Analyzing decentralized resource regimes from a polycentric perspective”, Policy Sciences, Vol. 41 No. 1, pp. 71-93, doi: 10.1007/s11077-007-9055-6.

Anheier, H.K. (2014), Nonprofit Organizations: Theory, Management, Policy, 2nd ed., Routledge, New York.

Asante, F.A. and Ayee, J.R. (2008), "Decentralization and poverty reduction: the economy of Ghana analytical perspectives on stability, growth and poverty", in Aryeetey, E., Harrigan, J. and Nissanke, M. (Eds), The Economy of Ghana, James Currey \& Woeli Publishing Services.

Babacan, M. (2011), "Economics of philanthropic institutions, regulation and governance in Turkey", Journal of Economic and Social Research, Vol. 13 No. 2, pp. 61-89.

Baldwin, K. and Sukmana, R. (2016), "Hedging displaced commercial risk", Review of Financial Economics, February, pp. 1-19.

Bank Negara Malaysia (2012), Shariah Standard on Mudarabah, Islamic Banking and Takaful Department, Bank Negara Malaysia, available at: https://law.resource.org/pub/my/ibr/ms.bnm. shariah.mudarabah.2012.pdf (accessed 30 December 2020).

Birla, B. and Taneja, U. (2008), "Public private partnerships for healthcare delivery in India", Internet Journal World Health Societal Politics, Vol. 7 No. 1, pp. 1-17.

Brinkerhoff, D.W., Cross, H.E., Sharma, S. and Williamson, T. (2019), "Stewardship and health systems strengthening: an overview", Public Administration and Development, Vol. 39 No. 1, pp. 4-10.

Carlisle, K. and Gruby, R.L. (2019), "Polycentric systems of governance: a theoretical model for the commons", Policy Studies Journal, Vol. 47 No. 4, pp. 927-952.

Chalil, T.M. (2020), "Rethinking corruption on fiscal decentralization and global competitiveness Nexus”, Competitiveness Review, Vol. 30 No. 5, pp. 507-527, doi: 10.1108/CR-04-2019-0039.

Chee-Khoon, C. (2007), "The welfarist state under duress: global influences and local contingencies in Malaysia", in Leng, C.H. and Barraclough, S. (Eds), Health Care in Malaysia: the Dynamics of Provision, Financing and Access, Routledge Malaysian Studies Series, pp. 85-101.

Çizakça, M. (1996), A Comparative Evolution of Business Partnerships: the Islamic World and Europe, with Specific Reference to the Ottoman Archives, Vol. 8, Brill, London.

Çizakça, M. (1998), “Awqaf in history and its implications for modern Islamic economies", Islamic Economic Studies, Vol. 6 No. 1, pp. 43-70.

Çizakça, M. (2013), "The new waqf law prepared by IDB/IRTI and the Kuwait Public Foundation: a critical assessment", World Foundations Conference, pp. 23-24.

Cordery, C.J. and Baskerville, R.F. (2007), "Charity financial reporting regulation: a comparative study of the UK and New Zealand", Accounting History, Vol. 12 No. 1, pp. 7-27.

Costa-Font, J. and Perdikis, L. (2018), "Varieties of health care devolution: systems or federacies?", LEQS Discussion Paper Series No. 130/2018, available at: http://aei.pitt.edu/93613/ (accessed 25 January 2021).

Croke, K., Mohd Yusoff, M.B., Abdullah, Z., Mohd Hanafiah, A.N., Mokhtaruddin, K., Ramli, E.S., Borhan, N.F., Almodovar-Diaz, Y., Atun, R. and Virk, A.K. (2019), "The political economy of health financing reform in Malaysia”, Health Policy and Planning, Vol. 34 No. 10, pp. 732-739.

Dāhir, A.I. (2015), "Imārat al-Mujamma'at wa al-Mabānī al-Tibiyyah al-bayāmaristānāt fī al-Islām”, in Encyclopedia of Architecture in Islam, Vol. 10, available at: https://www.alukah.net/Books/Files/ Book_7089/BookFile/TBYAH.pdf (accessed 20 December 2019).

Drucker, P. (2011), Managing the Non-profit Organization: Principles and Practices, Routledge, London and New York.

Elasrag, H. (2017), "Towards a new role of the institution of waqf", Munich Personal RePEc Archive, Paper No. 80513. 
Fadime, Ç., Erenb, E. and Hatun, M. (2013), "Decentralization in health services and its impacts: SWOT analysis of current applications in Turkey", Procedia - Social and Behavioral Sciences, Vol. 99, pp. 711-718.

Farouk, U.K. and Wing, M.S. (2019), "Drivers and challenges of a NGO type social enterprise in Malaysia: a narrative study", Malaysian Journal of Consumer and Family Economics, Vol. 22 No. S1, pp. 43-66.

Freille, S., Haque, M.E. and Kneller, R.A. (2007), "Federalism, decentralisation and corruption", available at: http://mpra.ub.uni-muenchen.de/27535/ (accessed 25 January 2021).

Galasso, E. and Ravallion, M. (2005), "Decentralized targeting of an antipoverty program”, Journal of Public Economics, Vol. 89 No. 4, pp. 705-727.

Goel, R.K., Mazhar, U., Nelson, M.A. and Ram, R. (2017), "Different forms of decentralization and their impact on government performance: micro-level evidence from 113 countries", Economic Modelling, Vol. 62, January, pp. 171-183.

Guanais, F.C. and Macinko, J. (2009), "The health effects of decentralizing primary care in Brazil", Health Affairs, Vol. 28 No. 4, pp. 1127-1135.

Hamouche, M. (2007), "Sustainability \& urban management in old Muslim cities: the role of pious foundations", Journal of King Saud University, Vol. 19 No. 2, pp. 27-48.

Hamzi, M., Hidayah, N., Qistina, N. and Mahmud, A. (2020), "Overview of public private partnership in primary health care in Malaysia: a scoping review", International Journal of Public Health and Clinical Sciences, Vol. 7 No. 3, pp. 129-147.

Hanefah, M.B.M., Kamaruddin, M.I.H., Masruki, R. and Ismail, M.M. (2020), “Corporate governance and performance of Shariah-compliant companies", in Handbook of Research on Theory and Practice of Global Islamic Finance, IGI Global, Pennsylvania, pp. 547-566.

Hassan, A.A.H. (2007), "Sales and contracts in early Islamic commercial law", No. 92, The Other Press, Petaling Jaya.

Hassan, M.K. (Ed.) (2016), Handbook of Empirical Research on Islam and Economic Life, Edward Elgar Publishing, Cheltenham, UK and Northampton, MA, USA.

Hassan, R. and Noor, F.M. (2020), "Islamic good governance for waqf institutions: a proposed framework", in Handbook of Research on Theory and Practice of Global Islamic Finance, IGI Global, Pennsylvania, pp. 424-439.

Ibrahim, S.S.B., Mohd Nor, A.H. and M Don, M.A. (2019), "Performance of waqf cross-sector collaboration: a systematic literature review (SLR) approach”, Journal of Muwafaqat, Vol. 2 No. 2, pp. 93-103.

Independent Evaluation Group (2016), Public-Private Partnerships in Health: World Bank Group Engagement in Health PPPs, World Bank, Washington DC.

'Isā, I. (1981), Tañkh al-bayāmaristānāt Fì al-Istām, Dār al-Ra'id al-Arabi, Beirut.

Ismail, S. and Harris, F.A. (2014), "Challenges in implementing public private partnership (PPP) in Malaysia”, Procedia-Social and Behavioral Sciences, Vol. 164, pp. 5-10.

Isufaj, M. (2014), "Decentralization and the increased autonomy in local governments", Procedia-Social and Behavioral Sciences, Vol. 109, pp. 459-463.

Jensen, J. (2016), “A review of public-private partnership activities in health system strengthening”, in The Role of Public-Private Partnerships in Health Systems Strengthening: Workshop Summary, National Academies Press (US), Washington DC.

Kälin, W. (1999), "Decentralization-why and how", Decentralization and Development, Bern: Swiss Agency for Development and Cooperation Publications on Development.

Koivusalo, M., Wyss, K. and Santana, P. (2007), "Effects of decentralization and recentralization on equity dimensions of health systems", in Saltman, R.B., Bankauskaite, V. and Vrangbæk, K. (Eds), Decentralization in Health Care, Open University Press, London. 
IJIF

14,1

Kuran, T. (2001), "The provision of public goods under Islamic law: origins, impact, and limitations of the waqf system", Law and Society Review, Vol. 35 No. 4, pp. 841-898.

Kuran, T. (2003), "The Islamic commercial crisis: institutional roots of economic underdevelopment in the Middle East", Journal of Economic History, Vol. 63 No. 2, pp. 414-446.

Lorz, O. and Willmann, G. (2013), "Size versus scope: on the trade-off facing economic unions", International Tax and Public Finance, Vol. 20 No. 2, pp. 247-267.

Maino, F., Blomqvist, P., Bertinato, L., Bohígas, L., SantasusagnaGarrido, R.M.U. and Shishkin, S. (2007), "Effects of decentralization and recentralization on political dimensions of health systems", in Saltman, R.B., Bankauskaite, V. and Vrangbæk, K. (Eds), Decentralization in Health Care, Open University Press, London.

Mansor, N., Jamil, A. and Bahari, A. (2018), "Waqf reporting: a modified integrated reporting for sustainable Islamic social finance", International Journal of Academic Research in Business and Social Sciences, Vol. 8 No. 12, pp. 1-12.

Masruki, R. and Shafii, Z. (2013), "The development of waqf accounting in enhancing accountability", Middle-East Journal of Scientific Research, Vol. 13 No. 13, pp. 1-6.

Mathias, J.D., Lade, S.J. and Galaz, V. (2017), "Multi-level policies and adaptive social networks: a conceptual modeling study for maintaining a polycentric governance system", International Journal of the Commons, Vol. 11 No. 1, pp. 220-247.

McGinnis, M. (2005), "Costs and challenges of polycentric governance", Workshop on Analyzing Problems of Polycentric Governance in the Growing EU, Berlin, Humboldt University.

Merwe, S.E., Biggs, R. and Preiser, R. (2018), "Building social resilience in socio-technical systems through a participatory and formative resilience assessment approach", Systemic Change Journal, Vol. 1 No. 1, pp. 1-34.

Mobin, M.A. and Ahmad, A.U.F. (2017), "Achieving sustainable economic development through Islamic microfinance and the potential of a proposed two-tier mudarabah waqf business model", in Handbook of Empirical Research on Islam and Economic Life, pp. 193-212.

Nahar, H.S. and Yaacob, H. (2011), "Accountability in the sacred context", Journal of Islamic Accounting and Business Research, Vol. 2 No. 2, pp. 87-113.

Nexus Partnerships Limited (2019), Public Private Partnerships in Malaysia, available at: http://www. commonwealthgovernance.org/countries/asia/malaysia/public-private-partnerships/ (accessed 15 June 2019).

Nour, H. (2012), "Awqaf and heritage urban conservation in historic Muslim cities: the case of waqf institution in historic Cairo", Unpublished manuscript, Politecnico di Milano, Italy.

Nour, H. (2015), "Reconsidering the waqf: traditional mechanism of urban regeneration in historic Muslim cities", International Journal of Architectural Research: ArchNet-IJAR, Vol. 9 No. 1, pp. 18-30.

Nowsheravi, A. (1983), "Muslim hospitals in the medieval period", Islamic Studies, Vol. 22 No. 2, pp. 51-62.

Oates, W.E. (2006), "On the theory and practice of fiscal decentralization”, IFIR Working Paper No. 2006-05, available at: https://martin.uky.edu/sites/martin.uky.edu/files/IFIR/Pub/ifir-wp-200605.pdf (accessed 20 January 2019).

Ostrom, V. (1972), "Polycentricity", Paper presented at the Annual Meeting of the American Political Science Association, Washington, D.C., September 5-9.

O'Grady, W. (2019), "Enabling control in a radically decentralized organization”, Qualitative Research in Accounting and Management, Vol. 16 No. 2, pp. 224-251.

Phommasack, B., Oula, L., Khounthalivong, O., Keobounphanh, I., Misavadh, T., Oudomphone, P., Vongsamphanh, C. and Blas, E. (2005), "Decentralization and recentralization: effects on the health systems in Lao PDR", Southeast Asian J Trop Med Public Health, Vol. 36 No. 2, pp. 523-528. 
Prud'homme, R. (1995), “The dangers of decentralization”, The World Bank Research Observer, Vol. 10 No. 2, pp. 201-220.

Raffler, P., Posner, D.N. and Parkerson, D. (2019), The Weakness of Bottom-Up Accountability: Experimental Evidence from the Ugandan Health Sector, Innovations for Poverty Action, Los Angeles.

Rafie, M. and Shuib, S.M. (2018), "Public private partnership (PPP) in Malaysia", International Journal of Business and Management, Vol. 2 No. 4, pp. 9-13.

Raman, A.V. (2012), Public Private Partnership in Health Care: Context, Models and Lessons, Faculty of Management Studies, University of Delhi.

Ramli, N.M., Mohd Salleh, N.H. and Muhamed, N.A. (2015), "Discharging accountability through governance: cases from Waqf institutions in Indonesia", Online Journal of Research in Islamic Studies, Vol. 2 No. 1, pp. 1-13.

Regmi, K., Naidoo, J., Greer, A. and Pilkington, P. (2010), "Understanding the effect of decentralisation on health services: the Nepalese experience", Journal of Health Organization and Management, Vol. 24 No. 4, pp. 361-382.

Rondinelli, D.A., Mccullough, J.S. and Johnson, R.W. (1989), “Analysing decentralization policies in developing countries: a political-economy framework", Development and Change, Vol. 20 No. 1, pp. $57-87$.

Saad, N.M., Sarif, S.M., Osman, A.Z., Hamid, Z. and Saleem, A.Y. (2017), "Managing corporate waqf in Malaysia: perspectives of selected SEDCs and SIRCs", Jurnal Syariah, Vol. 25 No. 1, pp. 91-116.

Saduman, S. and Aysun, E.E. (2009), "The socio-economic role of waqf system in the Muslim-Ottoman cities' formation and evolution", Trakia Journal of Sciences, Vol. 7 No. 2, pp. 272-275.

Sapri, M., Hariati, A.H., Sheau Ting, L. and Sipan, I. (2016), "Public private partnership benefits in delivering public facilities in Malaysia”, MATEC Web of Conferences, Vol. 66 No. 00014, available at: https://cyberleninka.org/article/n/701612/viewer.

Sayili, A. (2006), "The emergence of the prototype of the modern hospital in medieval Islam", Studies in the History of Medicine, Vol. 4, pp. 114-115.

Schoon, M.L., Robards, M.D., Meek, C.L. and Galaz, V. (2015), "Principle 7 - promote polycentric governance systems", in Biggs, R., Schluter, M. and Schoon, M.L. (Eds), Principles for Building Resilience: Sustaining Ecosystem Services in Social-Ecological Systems, pp. 226-250.

Shafii, Z., Iqbal, Z. and Mustafa, T. (2015), Governance Regulatory Framework for Waqf in Selected Countries, World Bank Global Islamic Finance Development Centre, Borsa Istanbul.

Shah, A. and Thompson, T. (2004), Implementing Decentralized Local Government: A Treacherous Road with Potholes, Detours and Road Closures, Vol. 3353, World Bank Publications.

Shefer-Mossensohn, M. (2014), "The many masters of Ottoman hospitals: between the imperial palace, the harem, bureaucracy, and the Muslim law courts", Turkish Historical Review, Vol. 5 No. 1, pp. 94-114.

Suhaili, N.A., Palil, M.R. and Husin, R. (2018), "Wakaf CSR: an empirical study of polycentric collaborative waqf governance”, Jurnal Pengurusan, Vol. 53, pp. 133-146.

Sundaram, J.K. and Chowdhury, A. (2009), "Reconsidering public-private partnerships in developing countries", International Journal of Institutions and Economies, Vol. 1 No. 2, pp. 191-205.

Taamneh, M., Rawabdeh, M.A. and Abu-Hummour, A.M. (2019), "Evaluation of decentralization experience through political, administrative, and fiscal indicators: the case of Jordan", Journal of Public Affairs, Vol. 20 No. 2, doi: 10.1002/pa.2026.

Thiel, A. (2016), "The polycentricity approach and the research challenges confronting environmental governance”, THESys Discussion Paper No. 2016-1.

Tkachenko, Y.U. and Kulyk, Y.U. (2019), "Decentralization and territorial consolidation in Ukraine as the latest trend of the global partnership", Financial and Credit Activity: Problems of Theory and Practice, Vol. 1 No. 28, pp. 414-421. 
IJIF

14,1

88

Tobbala, S. (2019), "Towards a decentralized governance system in Egypt", Journal of Public Policy and Administration, Vol. 4 No. 2, pp. 13-32.

Tschanz, D.W. (2017), "The Islamic roots of the modern hospital", available at: https://www. aramcoworld.com/Articles/March-2017/The-Islamic-Roots-of-the-Modern-Hospital (accessed 1 March 2021).

Udovitch, A.L. (2011), Partnership and Profit in Medieval Islam, Princeton University Press, Princeton, NJ.

UKAS (2021), About UKAS, available at: https://www.ukas.gov.my/en/about-ukas (accessed 13 September 2021).

UNDP/EU (2019), "Mapping of development partners' interventions in supporting local governance: local development in Jordan, UNDP/EU decentralisation and local development support Programme 2019-2017", available at: https://www.jo.undp.org/content/dam/jordan/docs/Donorsmapping-report-Final-22-33.pdf (accessed 13 January 2020).

Vrangbæk, K. (2007), "Key factors in assessing decentralization and recentralization in health systems", in Saltman, R.B., Bankauskaite, V. and Vrangbæk, K. (Eds), Decentralization in Health Care, Open University Press, London, pp. 63-76.

White, S. (2011), Government Decentralization in the 21st Century: a Literature Review. A Report of the CSIS Program on Crisis, Conflict and Cooperation, Center For Strategic and International Studies, Washington.

World Bank (2019), South Asia Economic Focus: Rethinking Decentralization, The World Bank, Washington.

World Health Assembly 53 (2000), "Fifty-third World Health Assembly", 15-20 May 2000, World Health Organization, Geneva.

Yaacob, H., Petra, S., Sumardi, A. and Nahar, H.S. (2015), "Accountability through accounting and reporting lenses”, Humanomics, Vol. 31 No. 3, pp. 299-313.

\section{About the authors}

Raja Aishah binti Raja Adnan is currently a $\mathrm{PhD}$ candidate at the Faculty of Leadership and Management, Universiti Sains Islam Malaysia, Negeri Sembilan, Malaysia. Raja Aishah binti Raja Adnan is the corresponding author and can be contacted at: raishahra2@gmail.com

Mahazan Abdul Mutalib, PhD, is Associate Professor at the Faculty of Leadership and Management, Universiti Sains Islam Malaysia, Negeri Sembilan, Malaysia. His areas of specialization are Islamic leadership and management. He is also a mentor for Knowledge for Change program, UNESCO.

Muhammad Ridhwan Ab. Aziz, PhD, is Professor and Dean at the Faculty of Economics and Muamalat, Universiti Sains Islam Malaysia, Negeri Sembilan, Malaysia. His areas of specialization are Islamic banking and finance as well as Islamic social finance.

For instructions on how to order reprints of this article, please visit our website:

www.emeraldgrouppublishing.com/licensing/reprints.htm

Or contact us for further details: permissions@emeraldinsight.com 